\title{
Knowledge Management and Customer Relationship Management for Accounting Services Companies
}

\author{
Mirela Elena Nichita, Marcel Vulpoi \\ Bucharest Academy of Economic Studies, Bucharest, Romania \\ Georgiana Toader \\ Bucharest Academy of Economic Studies, Bucharest, Romania \\ SC Vulpoi \& Toader Management SRL, Bucharest, Romania
}

\begin{abstract}
By combining the abilities to respond directly to customer requests and to provide the customer with a highly interactive, customized experience, companies have a greater ability today to establish nurture and sustain long-term customer relationships than ever before. The ultimate goal is to transform these relationships into greater profitability by increasing repeat purchase rates and reducing customer acquisition costs. Customer relationship management (CRM) has a significant potential to leverage an organization's performance, but it does not come without a clear sense of destination and typically without pain. For the research methodology we use the database of customers of a Romanian accounting services company Vulpoi \& Toader Management SRL, which is an important player in this market. The goal of our paper is to find out the link between knowledge management (KM) and CRM for this company and how these "innovations" contribute to increasing the value of the business.
\end{abstract}

Keywords: knowledge management (KM), customer relationship management (CRM), accounting, profit, value of business

\section{Introduction}

By combining the abilities to respond directly to customer requests and to provide the customer with a highly interactive, customized experience, companies have a greater ability today to establish nurture and sustain long-term customer relationships than ever before. The ultimate goal is to transform these relationships into greater profitability by increasing repeat purchase rates and reducing customer acquisition costs. Customer relationship management (CRM) has a significant potential to leverage an organization's performance, but it does not come without a clear sense of destination and typically without pain. Success requires leadership, honesty, and pragmatism. At its core, CRM is a simple, intuitively appealing concept:

Mirela Elena Nichita, Ph.D., Lecturer, Department of Accounting, Audit and Economical Analysis, Bucharest Academy of Economic Studies.

Marcel Vulpoi, Ph.D., Lecturer, Department of Accounting, Audit and Economical Analysis, Bucharest Academy of Economic Studies.

Georgiana Toader, Ph.D. candidate, Bucharest Academy of Economic Studies; Managing Partner at SC Vulpoi \& Toader Management SRL.

Correspondence concerning this article should be addressed to Mirela Elena Nichita, Piața Romană, nr. 6-8, sector 1, Bucuresti, Romania. E-mail: mirela.nichita@cig.ase.ro. 
attract new customers, know them well, give them outstanding service, and anticipate their wants and needs. When companies do these things well, increased revenues and profits are likely to follow. But CRM means different things to different people, and it is being implemented in different ways. For some companies, CRM means creating offers to customers based on their past behaviours and demographic characteristics. To others, it means giving service representatives information about customer profitability and how customers generate profits. To still others, it means changing the appearance of a website based on customer profiles and preference information. At the same time, companies have integrated their CRM and knowledge management (KM) efforts because they realize that KM plays a key role in CRM success. For the research methodology we use the database of customers of a Romanian accounting services company Vulpoi \& Toader Management SRL, which is an important player in this market. The goal of our paper is to find out the link between KM and CRM for this company and how these "innovations" contribute to increasing the value of business.

CRM has been recognized since the mid-1990s; due mainly to the fact that industries were experiencing demand from their customers for higher and less fuzzy access to the service. This emphasis on renewed customer service drove corporations and the top managers to rethink the traditional ways of providing services. Recent studies show that the movement to CRM is gaining momentum. One survey of more than 1,500 companies by The Data Warehousing Institute (TDWI) in 2000 found that $91 \%$ either have or plan to deploy a CRM solution in the near future.

CRM and KM initiatives are directed towards the same goal: the delivery of continuous improvement towards customers. Initiatives stemming from this effort have been labeled "customer knowledge management" (CKM) or "knowledge-enabled CRM" (Gibbert, Leibold, \& Probst, 2002; Geib \& Riempp, 2002; Geib, Reichold, Kolbe, \& Brenner, 2005). In this contribution, we conceptualize CKM as the utilization of knowledge for, from, and about customers in order to enhance the customer-relating capability of organizations.

\section{CRM}

At its core, CRM is a simple, intuitively appealing concept: attract new customers, know them well, give them outstanding service, and anticipate their wants and needs. When companies do these things well, increased revenues and profits are likely to follow. But CRM means different things to different people, and it is being implemented in different ways. For some companies, CRM means creating offers to customers based on their past behaviours and demographic characteristics. To others, it means giving service representatives information about customer profitability and how customers generate profits.

We have found three important CRM targets:

- Applications-Individual CRM applications that deliver business value;

- Infrastructure-A data, software, and hardware infrastructure that supports CRM applications and will also support future applications;

- Transformation-An organizational transformation made possible through comprehensive CRM efforts. In the 1990s, relationship marketing (also called 1:1 marketing) emerged. It focused on developing and maintaining relationships with individual customers and relied on a two-way dialogue between a company and a customer to develop a deep relationship.

In Table 1, you will find the targets that Goodhue, Wixom, and Watson (2002) stated in their research. 
Table 1

The Targets of CRM

\begin{tabular}{|c|c|c|c|}
\hline Target & Individual applications & CRM infrastructure & Organizational transformation \\
\hline $\begin{array}{l}\text { The three targets } \\
\text { have quite different } \\
\text { organizational } \\
\text { costs and benefits. }\end{array}$ & $\begin{array}{l}\text { Costs are relatively low. } \\
\text { Greater efficiencies and } \\
\text { effectiveness at res the } \\
\text { departmental level may result } \\
\text { in greater local revenues and } \\
\text { profits. }\end{array}$ & $\begin{array}{l}\text { Infrastructure creation is costly, requires } \\
\text { a "vision" to justify. Departments give } \\
\text { up control of "their" data. Possible cost } \\
\text { savings from infrastructure } \\
\text { consolidation. } \\
\text { Possible "quick hit" returns from } \\
\text { follow-on applications. }\end{array}$ & $\begin{array}{l}\text { An expensive, risky undertaking, } \\
\text { but with the potential for great } \\
\text { increases in revenues and profits. }\end{array}$ \\
\hline $\begin{array}{lr}\text { Sponsorship may } \\
\text { vary across } \\
\text { targets. }\end{array}$ & $\begin{array}{l}\text { Usually initiated at the } \\
\text { department level. }\end{array}$ & $\begin{array}{l}\text { Often initiated by corporate IT, but } \\
\text { must also enlist wider business } \\
\text { sponsorship. }\end{array}$ & $\begin{array}{l}\text { Initiated by top management, but } \\
\text { must enlist all levels of the } \\
\text { organization. }\end{array}$ \\
\hline $\begin{array}{l}\text { Plan for the } \\
\text { evolution of your } \\
\text { CRM efforts. }\end{array}$ & $\begin{array}{|lr|}\text { Multiple } & \text { individual } \\
\text { applications may lead to } \\
\text { demands for coordination, } \\
\text { better infrastructure. }\end{array}$ & $\begin{array}{l}\text { Once the infrastructure is in place, } \\
\text { many individual applications become } \\
\text { possible. Organizational transformation } \\
\text { also becomes possible. }\end{array}$ & $\begin{array}{l}\text { Usually involves new } \\
\text { infrastructure and new applications } \\
\text { to support new business practices. }\end{array}$ \\
\hline $\begin{array}{l}\text { Prepare to work } \\
\text { with CRM data. }\end{array}$ & $\begin{array}{l}\text { Needed data are limited in } \\
\text { scope and volume. Integration } \\
\text { problems are easier to solve } \\
\text { because the data are } \\
\text { controlled at the departmental } \\
\text { level. }\end{array}$ & $\begin{array}{l}\text { Large amounts of data are needed from } \\
\text { disparate source systems owned by } \\
\text { different constituents, frequently } \\
\text { without common identifiers. Difficult } \\
\text { challenge. }\end{array}$ & $\begin{array}{l}\text { All the problems of the } \\
\text { infrastructure target, with the } \\
\text { added challenge of supporting new } \\
\text { business processes with a changing } \\
\text { data infrastructure. }\end{array}$ \\
\hline $\begin{array}{l}\text { Ensure the technical } \\
\text { infrastructure will } \\
\text { scale to meet future } \\
\text { challenges. }\end{array}$ & $\begin{array}{l}\text { Requirements are localized } \\
\text { and easier to understand and } \\
\text { predict. }\end{array}$ & $\begin{array}{l}\text { Need to support a multitude of users } \\
\text { and applications. Harder to understand } \\
\text { and predict requirements. Must be } \\
\text { highly scalable. }\end{array}$ & $\begin{array}{l}\text { All the problems of the } \\
\text { infrastructure target, with the } \\
\text { added challenge of supporting new } \\
\text { business processes with a changing } \\
\text { technical infrastructure. }\end{array}$ \\
\hline $\begin{array}{l}\text { You can teach } \\
\text { old dogs new } \\
\text { tricks... } \\
\text { sometimes. }\end{array}$ & $\begin{array}{l}\text { Only a small group of users } \\
\text { must learn to work with new } \\
\text { applications. }\end{array}$ & $\begin{array}{l}\text { A growing base of users must learn the } \\
\text { new decision support environment as } \\
\text { data become more available. IT } \\
\text { personnel must learn new skills and } \\
\text { technologies. }\end{array}$ & $\begin{array}{l}\text { Nearly everyone becomes a user in } \\
\text { some way. Jobs are changed, } \\
\text { eliminated, and created. Many } \\
\text { changes in job skills, both for } \\
\text { business and IT. }\end{array}$ \\
\hline
\end{tabular}

Note. Source: Goodhue, Wixom, \& Watson (2002).

Target 1: Individual applications. Some companies have a burning need for a specific CRM application and the "quick hit" benefits it can bring. The most popular applications are database marketing (56\% of the firms), telephone call-centres (53\%), web marketing (50\%), direct mail campaigns (49\%), field sales (40\%), web self-service (40\%), web portal (40\%), and e-mail marketing (37\%). Many companies are not ready to rush into a new way of working with an extensive enterprise-wide CRM effort; their situation and culture encourage a cautious approach - test and prove the concept before rolling it out across the organization.

Target 2: CRM infrastructure. CRM applications need an underlying technical infrastructure to provide not only the computing power and telecommunications links to connect applications to each other but also logical data consistency so the applications can share information. CRM implies that companies should interact in a coordinated manner with their customers, across all customer touch points and channels. Without this coordination, communications with customers will be inconsistent, less useful to customers, and have less impact. Thus, companies not only need to store large amounts of data but all their CRM applications need to be able to tap into that data. This sharp-ability requires a data infrastructure incorporating common data models and data standards to which the applications adhere. And it requires a hardware and software infrastructure that provides high-volume storage and fast data retrieval. When organizations focus on their CRM data infrastructure, they usually have potential applications in mind, but they seek first to put in place a data 
resource that is integrated across various source systems and customer touch points; uses a single, unique identifier for every customer; and keeps the data accurate, timely, and reliable.

Target 3: Organizational transformation. For most firms, becoming truly "customer-centric" involves a major shift in organizational culture and business practices. But organizational transformation of this magnitude is difficult and fraught with opportunities for failure.

\section{Research Method}

The central research question for this study was: What are the strategic implications of the implementation and use of CRM systems? In the light of this, a case study approach was adopted as it enables the researcher to pose questions relating to what happened, how things happened and why. The case study therefore illustrates the first steps of a Romanian company that is implementing CRM.

Established in 2004, SC Vulpoi \& Toader Management SRL (VTM) is one of the largest Romanian companies offering "one stop shop" accounting and business consultancy services through a multidisciplinary team of 70 professionals (Retrieved from http://www.vtm.ro). VTM has grown at a rapid pace to serve the complex needs of a portfolio of over 300 clients active in various industries such as: oil, IT services, mobile telephony, constructions, trade, cinematography, and real estate. The data for the study were collected over the period of a year beginning at the selection stage and reaching closure at go-live. Throughout the study, data were collected via a number of channels including interviews with members of the project team and others within the company. Interviews were conducted with the directors of finance, the managers of sales, marketing, IT, and HRM. Documentary evidence, such as requirements specifications was also considered. Review meetings were also held with key contacts at the company.

The first major issue for VTM was the lack of knowledge pertaining to the concept of CRM. Strategic managers had a basic understanding of CRM. The IT department had little time to research CRM or to develop software solutions as it was often overstretched and struggling to maintain existing systems, so the company decides to purchase software specially designed for its needs.

The company starts the implementation of the CRM software at the beginning of this year; so far, we do not identify problems that could worry. All the team leaders have handbook in order to help them to fill in the database with information related to their customers. Figure 1 highlights our long-term strategy.

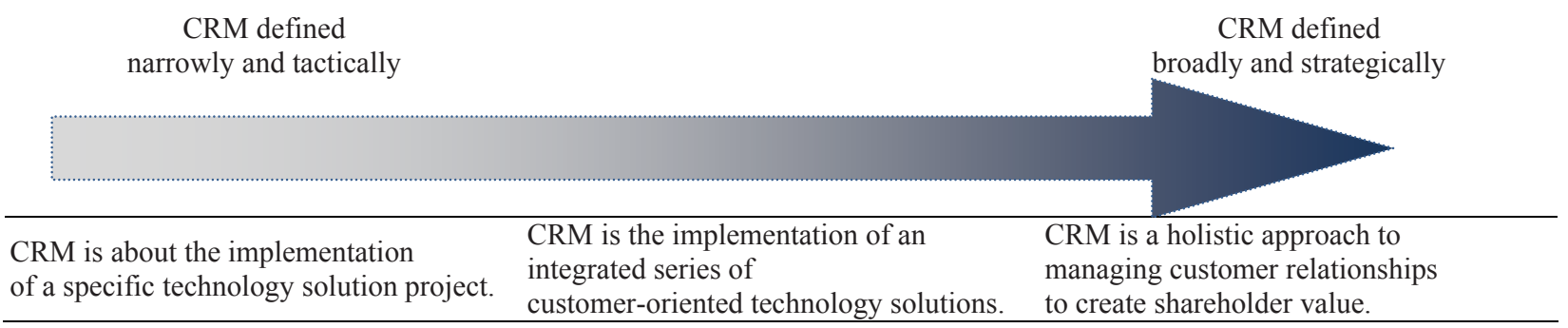

Figure 1. The CRM continuum. Source: The authors' own design.

At present, our paper is a work in progress. VTM starts to implement CRM at the beginning of 2012. In order to help the employees, VTM worked with a team of informatics and they developed a personalised CRM, Microsoft Dynamic CRM v1. To connect to CRM, each user has a username and a password. They can add, modify or cancel an action (lead), create a new contract, change some clauses of contract, and so on. Until now, the users are getting used with this new programme; we have to take into accountable that they are 
accountant, and they have to solve, first of all, the daily tasks and issues for clients. The Microsoft Dynamic CRM offers the possibility to create reports and charts using the included in its database. The company provides human resources services, financial advisory, and legal consultancy, which are, also, included in the CRM software.

Questionnaires and interviews are used as methods of collecting data and information.

\section{Does CRM Contribute to the Bottom Line?}

We discuss an issue critical to companies that invest in CRM: How to assess return on investment (ROI). A number of issues make this task challenging. First, defining the boundaries of CRM; second, establishing what constitutes a CRM investment; third, deciding what counts as a "return" on that investment; and finally, choosing the time frame to use in the assessment. Over recent years, the amount invested in CRM technology has exploded worldwide. Helms (2001) estimated that worldwide investment in CRM stood at $\$ 61$ billion. This is set to grow to $\$ 148$ billion by 2005 according to International Data Corporation. However, despite these huge sums, very little research has been published on whether such investments have made substantial returns to the company (Buttle, 2002).

There seems little doubt that CRM implementations have the capacity to improve managerial performance in the important areas of customer acquisition, customer development (migration), and customer retention. But what evidence is there that CRM has had a significant influence on overall corporate performance? In short, does CRM contribute to the bottom line?

Against this backdrop of success stories, our studies also have shown that CRM implementations often fail. It is suggested that between $70 \%$ and $90 \%$ of CRM implementations have failed (Brewton, cited in Buttle, 2002). Another estimate is that $30 \%-40 \%$ of CRM tactical projects have failed, while $60 \%$ of CRM projects that attempt a strategic focus have also failed (Woodstock, Starkey, Stone, Weston, \& Ozimek, 2001). Worse still, one in five CRM implementations are thought to have actually damaged customer relationships (Bain \& Company, Inc., 2005). If CRM's contribution to corporate performance is equivocal, what can companies do to evaluate its worth? How does one go about evaluating the ROI of CRM?

Return on investment is a simple idea. It computes thus:

$$
\text { ROI }=\text { Profits/Investment } \times 100
$$

It measures how much profit returns from a given investment. In the context of CRM, this simplicity is however complicated by:

(1) Defining the boundaries of CRM;

(2) Establishing what constitutes a CRM investment;

(3) Deciding what counts as a 'return' on that investment;

(4) Choosing the time frame to use in the assessment.

\section{Issue 1: Defining the Boundaries of CRM}

There is no consensus about what is meant by the term "CRM". Different constituencies having an interest in CRM have different emphases. Technology firms, want to sell software solutions into client organizations; consultants, like PwC and Accenture want to profit from helping clients and generate strong business outcomes from their CRM investments; clients typically want CRM to improve both cost and revenue sides of the profit equation. 


\section{Issue 2: Establishing What Constitutes a CRM Investment}

Most CRM projects in larger companies take between three and five years to implement. The technology component typically is a large investment at the outset. However, over the full term of the CRM project, technology costs account for between one-third and one-fifth of overall costs. Other costs are incurred in changing two other core elements of CRM strategies: people and process. People may need to be re-skilled or retrenched; talent may need to be recruited.

\section{Issue 3: Deciding What Counts as a "Return"}

In the conventional ROI formula, return is defined as profit. CRM outcome performance indicators can also be viewed more holistically from a number of domains based upon the balanced scorecard (Kaplan \& Norton, 1996). These include:

- Financial indicators like return on assets, EBIT, and profit on sales;

- Customer indicators like numbers of customers, average customer value, customer satisfaction, customer retention, and share of customer spend;

- The process results like customer acquisition cost, speed to market (new products);

- Complaint resolution;

- People indicators like percentage cross-trained, employee satisfaction, employee retention, and suggestions per employee.

\section{Issue 4: Choosing the Time Frame to Use in the Assessment}

CRM implementations may take up to five years, and in some cases, more, to implement fully. Over this time not only can the competitive environment change, but also members of the management team which opted to "do" CRM may have left the company. We propose a customer-journey approach to assessing CRM performance. By customer-journey we mean the customer's transition from never-a-customer to always-a-customer. This has been described by others (Christopher, Payne, \& Ballantyne, 1991) as a customer staircase or ladder. On this journey the value of customers will change. We imagine the complete journey as comprising seven stages, as follows:

- Suspect — could the customer fit our target market profile;

- Prospect - customer fits the profile and is being approached for the first time;

- First-time customer - customer makes first purchase;

- Repeat customer - customer makes more purchases;

- Majority customer - customer selects your product/company as supplier of choice;

- Loyal customer - customer is resistant to switching suppliers, strong attitude;

- Advocate-customer generates additional referral money.

We hope that our research will help us to find answers to the following questions:

Q1: Will the company achieve better business performance?

Q2: Will the company be incentive for their people to achieve specific targets for customer' acquisition, development, and retention in order to achieve better business performance?

Q3: The more the senior management team understands the enterprise-wide aspects of CRM, the greater the success of CRM implementations.

Q4: That the company has a customer-centric culture is more likely to be successful in CRM implementation. 
Q5: Being a service company, the implementation of CRM practices is more likely to see quicker benefits than product-based, manufacturing companies.

\section{Conclusions}

Theoretically it might be possible to build a CRM solution and roll it out to an organization at once, along with the many organizational changes that would be necessary for organizational transformation to a new CRM mindset. In practice, though, we have not seen this approach used, even in firms that start with organizational transformation as an explicit goal. This reluctance is probably because starting with a complete CRM solution requires clarity of vision that seldom exists at the outset of a project - and it puts a huge cost burden up-front when the uncertainty about business benefits is highest. CRM is a complex and holistic concept requiring appropriate business processes and integrated systems. In addition, the study demonstrates the relevance of the need for effective leadership, sourcing, targeting, and evaluation within CRM strategies.

\section{References}

Ang, L., \& Buttle, F. (2002). ROI on CRM: A customer-journey approach. Retrieved from http://impgroup.org/uploads/papers/4225.pdf

Bain \& Company, Inc. (2005). Management tools and trends 2005 . Retrieved from http://www.bain.com/management_tools/management_tools_and_trends_2005.pdf

Bull, C. (2003). Strategic issues in customer relationship management (CRM) implementation. Business Process Management Journal, 9(5), 592-602.

Buttle, F. (2002). ROI on CRM. Proceedings of the Academy of Marketing Annual Conference. Nottingham, UK.

Buttle, F. A. (2001). The CRM value chain. Retrieved from http://www.CRM-forum.com

Christopher, M., Payne, A., \& Ballantyne, D. (1991). Relationship marketing: Bringing quality, customer service and marketing together. Oxford: Butterworth Heinemann.

Croteau, A. M., \& Li, P. (2003). Critical success factors of CRM technological initiatives. Canadian Journal of Administrative Sciences, 20(1), 21-34.

Dous, M., Kolbe, L., Salomann, H., \& Brenner, W. (2005). Knowledge management capabilities in CRM: Making knowledge for, from and about customers work. Retrieved from https:/www.alexandria.unisg.ch/export/DL/214029.pdf

Dragomir, R., \& Tascovici, D. (2009). The customers relationships management-A strategical element in business promotion. Retrieved from http:/www.fse.tibiscus.ro/anale/Lucrari2009/015.\%20Dragomir,\%20Tascovici.pdf

Dyche, J. (2001). The CRM handbook. Boston: Addison-Wesley.

Fahey, L. (2001). Linking e-business and operating processes: The role of knowledge management. IBM Systems Journal, 40(4), 889-907.

Geib, M. et al. (2005). Architecture for customer relationship management approaches in financial services. Proceedings of the 38th Hawaii International Conference on System Sciences 2005 (HICSS-38). IEEE Computer Society, Big Island, Hawaii.

Geib, M., Kolbe, L. M., \& Brenner, W. (2004). Collaborative customer management in financial services alliances. Proceedings of the Tenth Americas Conference on Information Systems (AMCIS 2004) (pp. 3805-3817). New York City, NY.

Geib, M., \& Riempp, G. (2002). Customer knowledge management (pp. 393-417). Berlin: Springer.

Geib, M., Reichold, A., Kolbe, L. M., \& Brenner, W. (2005). Architecture for customer relationship management approaches in financial services. Proceedings of the 38th Hawaii International Conference on System Sciences 2005 (HICSS-38). Big Island, Hawaii.

Gibbert, M., Leibold, M., \& Probst, G. (2002). Five styles of customer knowledge management, and how smart companies use them to create value. European Management Journal, 20(5), 459-469.

Goodhue, D., Wixom, B., \& Watson, H. (2002). Realizing business benefits through CRM: Hitting the right target in the right way. MIS Quarterly Executive, 1(2), 79-94.

Helms, C. (2001). Promising ROI keeps CRM expenditures high. Retrieved from http://www.1to1.com/ 
Henderson, J. C., \& Vankatraman, N. (1993). Strategic alignment: Leveraging information technology for transforming organizations. IBM Systems Journal, 32(1), 4-16.

Kaplan, R., \& Norton, D. (1996). The balanced scorecard. Boston: Harvard Business School Press.

Kotter, J. P. (1995). Leading change: Why transformation efforts fail. Harvard Business Review, 73(2), 59-67.

Massey, A. P., Montoya-Weiss, M. M., \& Holcom, K. (2001). Re-engineering the customer relationship: Leveraging knowledge assets at IBM. Decision Support Systems, 32(2), 155-170.

McKenna, R. (1991). Relationship marketing: Successful strategies for the age of the customer. Massachusetts: Addison-Wesley. Olaru, A. (2003). Managementul afacerilor. Galați: Editura Academica.

Payne, A., \& Frow, P. (2005). A strategic framework for customer relationship management. Journal of Marketing, 69, $167-176$. Peppers, D., \& Rogers, M. (1993). The one to one future: Building relationships one customer at a time. New York: Doubleday.

Romano, A. C. (2000). Customer relations management in information system research. Proceedings of the Americas Conference in Information Systems (AMCIS) (pp. 811-819).

Smith, A. (2006). CRM and customer service: Strategic asset or corporate overhead? (pp. 87-93). Bingley, UK: Emerald Group Publishing Limited.

The Data Warehousing Institute. (2002). TDWI industry study 2000: Harnessing customer information for strategic advantage: Technical challenges and business solutions. Retrieved from http://www.tdwi.org

Wilson, H., Daniel, E., \& McDonald, M. (2002). Factors for success in customer relationship management (CRM) systems. Retrieved from http://dx.doi.org/10.1362/0267257022775918

Winer, R. S. (2001). A framework for customer relationship management. California Management Review, 43(4), 89-105.

Woodstock, N., Starkey, M., Stone, M., Weston, P., \& Ozimek, J. (2001). State of the nation II: 2002. An ongoing global study of how companies manage their fustomers. http://www.ebusinessforum.gr/engine/index.php?op=modload\&modname=Downloads\&action=downloadsviewfile \&ctn=688 \&language $=\mathrm{el}$ 